\title{
Effect of Faba Bean Sowing Distance and Some Combinations of Mineral Nitrogen Levels With Bio Fertilizers on Sugar Beet and Faba Bean Productivity Under Intercropping System
}

\author{
Moshira A. EL-Shamy, M. Kh. Hamadny and A. A. A. \\ Mohamed* \\ Crop Intensification Res. Sec., Field Crops Res. Inst., ARC \\ and *Agronomy Dept., Fac. Agric., Kafrelsheikh Univ., Kafr \\ EL-Sheikh, Egypt.
}

\begin{abstract}
A FIELD experiment was conducted at Sakha Agric. Res. Station, A Kafer EL-Sheikh Governorate, Egypt during 2013/2014 and 2014/2015 seasons to study the relative advantage of intercropping faba bean (variety Giza 643) with sugar beet (variety Geloria) and its impact on yield and quality attributes of both crops. A split plot design with three replications was used. The treatments of faba bean sowing distance $(10,20$ and $30 \mathrm{~cm})$ allocated in the main plots, while, the ten combination of nitrogen levels with bio fertilizers $(90,72,54,36 \mathrm{~kg}$ $\mathrm{N} / \mathrm{fad}, 72,54,36 \mathrm{~kg} \mathrm{~N} / \mathrm{fad}+$ Cerealine, 72, 54, $36 \mathrm{~kg} \mathrm{~N} / \mathrm{fad}+$ Rizobacterine) were arranged in sub plots, the obtained results showed that:

The planting space of $30 \mathrm{~cm}$ gave the greatest values of number of branches/ plant, number of pods /plant, number of seeds/plant, weight of 100 seeds, straw yield/fad, seeds yield/fad, protein percent, root diameter $(\mathrm{cm})$, fresh leaves weight/plant, fresh root weight/plant, dry leaves weight/plant, dry root weight /plant and root yield/fad (ton $\left.\mathrm{fad}^{-1}\right)$ in both seasons and at number of leaves /plant in the first seasons only, while the planting space of $10 \mathrm{~cm}$ recorded the lowest values in all previous characters. The treatment of $36 \mathrm{~kg} \mathrm{~N}$ level showed the lowest values at plant height $(\mathrm{cm})$, number of pods/plant, number of seeds/plant, weight of 100 seeds $(\mathrm{gm})$, seeds yield $\left(\right.$ ton $\left.\mathrm{fad}^{-1}\right)$, protein percent of faba bean, number of leaves /plant, root length $(\mathrm{cm})$, root diameter $(\mathrm{cm})$, fresh leaves weight/plant, fresh root weight/plant, dry leaves weight /plant, dry root weight /plant, root yield/fad(ton $\mathrm{fad}^{-1}$ ), sugars percent (\%), purity percent and TSS (\%) of sugar beet in the two growing seasons, while the treatments both of 90 and $72 \mathrm{~kg}$ mineral nitrogen as individual or $72 \mathrm{~kg}$ mineral nitrogen in combination with Cerealine or Rizobacterien recorded the highest significant values at all mentioned previous characters in both seasons. The interaction between $30 \mathrm{~cm}$ sowing distance of faba bean with both of 90 and $72 \mathrm{~kg}$ mineral nitrogen as individual or $72 \mathrm{~kg}$ mineral nitrogen in combination with Cerealine or Rizobacterien in both growing seasons recorded the highest values of the all studied characters while, the lowest values of those characters were recorded at the interaction between $10 \mathrm{~cm}$ faba bean sowing distance $36 \mathrm{~kg}$ mineral nitrogen as individual in both growing seasons. The highest values of Relative yield (RY), LER and net income of faba bean and
\end{abstract}


sugars beet were obtained from the interaction between $30 \mathrm{~cm}$ sowing distance of faba bean with both 90 and $72 \mathrm{~kg}$ mineral nitrogen as individual or in combination with Cerealine or Rizobacterien in both seasons.

It could be concluded that the highest productivity and best total net income of faba bean and sugars beet resulted from planting of faba bean at distance $30 \mathrm{~cm}$ under intercropping system with sugar beet with application of $72 \mathrm{~kg}$ mineral nitrogen in combination with bio fertilizers (Cerealine or Rizobacterien).

Keywords: Nitrogen and Bio fertilizer, Faba bean, Intercropping, Sowing distance, Sugar beet.

Sugar beet (Beta vulgaris L.) is the principle main source of sugar outside of the tropical areas of world, and it is the second crop for sugar production in Egypt after sugar cane; the importance of sugar beet crop to agriculture is not confined only to sugar production, but also it is adapted to saline, sodic and calcareous soils. Sugar beet is specialized as a short duration crop, where its growth period is about half that of sugar cane, furthermore, sugar beet requires less water. The aim of all investigators was to decrease the gap between production and consumption by increasing sugar production. Mahmoud et al. (2014) reported that application of $100 \mathrm{~kg}$ mineral $\mathrm{N} /$ fad produced the highest growth trait followed by Azot. + Azosp. with $80 \mathrm{~kg} \mathrm{~N} / \mathrm{fad}$. The highest values of TSS\%, sucrose $\%$, and recoverable sugar resulted from either Azoto. or Azosp.+ 60kg $\mathrm{N} /$ fad increasing $\mathrm{N}$ rates from 60 to $80 \mathrm{~kg} / \mathrm{fad}$ in combination with $\mathrm{N}$ fixing bacteria depressed beet quality and increased impurities in beet roots. The highest root and top yields resulted from $100 \mathrm{~kg} \mathrm{~N} / \mathrm{fad}$, while sugar yield was highest with the combination of Azto. + Azosp. with 60 or $80 \mathrm{~kg} \mathrm{~N} /$ fad followed by $100 \mathrm{~kg} \mathrm{~N} / \mathrm{fad}$

Faba beans (Vicia faba L.), one of the leguminous crops cultivated in Egypt and in the world and it can be used as human food in developing countries as green vegetable or dried, fresh, it is a source of several foods that in turn contain high proportion of protein (21 to $34 \%$ ), amino acids, fat and sugar (Aljubouri, 2006 and Hansen, 1972). Egypt is ranked the third in faba bean production (262 thousand tons year) and consumption after China and Ethiopia (9\%) and then Egypt 262 thousand tons /year. Kakahy et al. (2012) investigated the effect of planting distance on yield of faba beans (Vicia faba L.). The yield of three different varieties of beans (Spanish, Turkish and Local) at three different planting distances, including 10, 25 and $30 \mathrm{~cm}$ was studied. The results indicates that both, the interactions between plant distance and different varieties of faba bean did not significantly differed at $95 \%$ level of significance.

Intercropping faba bean with other crops has particular importance to replenish faba bean gap. Since 2001 the cultivated area has decreased from 333 thousands fad to less than 222 thousand fad in 2009 (due to the severe competition with wheat, berseem in winter season). Hussein \& EL-Deeb (2012) found that the highest seed yield was obtained when faba bean was intercropped

Egypt. J. Agron. Vol. 38, No.3(2016) 
with sugar beet at density of six or eight plants $/ \mathrm{m}^{2}$. Intercropping faba bean at four plants $\mathrm{m}^{-2}$ with sugar beet increased profitability by $12.5 \%$ over solid sugar beet. Mohammed et al. (2005) found that maximum values of land equivalent ratio 1.36 and 1.38 were obtained from intercropping $100 \%$ sugar beet with $33 \%$ faba bean in the first and second seasons, respectively along with the highest values of total income.

Bio-fertilizers are reasonably safer to the environment than chemical fertilizers and play an important role in decreasing the use of chemical fertilizers. Consequently, it causes a reduction environmental pollution. Soil inoculation with microorganisms may lead to increase soil available nitrogen and consequently increase formation of metabolites which encourage the plant vegetative growth and enhance the meristematic activity of tissues to produce more branches. The role of bio-fertilizers containing symbiotic or non-symbiotic nitrogen-fixing bacteria is improved the vegetative growth characters, yield and yield components.

Therefore, this study aimed to evaluate the yield and quality of both faba bean and sugar beet under intercropping system as affected by faba bean sowing distance and the combination between mineral nitrogen levels with bio fertilizers sources (Cerealine and Rizobacterine).

\section{Materials and Methods}

The field experiment was conducted at Sakha Agriculture Research Station, Kafer EL-Sheikh Governorate, (310 $07^{-} \mathrm{N}$ Latitude and $30057^{-} \mathrm{E}$ longitude with an elevation of about 6 meters above mean sea level) during 2013/2014 and 2014/2015 seasons to study the effect of the combination between mineral nitrogen levels with bio fertilizers sources and plant density on both faba bean (Vicia faba L.) and sugar beet (Beta vulgaris var. saccharifera, L.) production and quality attributes of both crops. Split plot design in three replications was used in this study. The present investigation included three treatments of faba bean distance 10, 20 and $30 \mathrm{~cm}$ (Equal plant density 70,000 - 35,000 - 17,500 plants / fad, respectively) which were occupied in the main plot, while the ten combinations between mineral nitrogen levels with bio fertilizers sources \{Control treatment (equal recommended rate of $90 \mathrm{~kg} / \mathrm{fad}$ ), $40 \%$ of control treatment, $60 \%$ of control treatment, $80 \%$ of control treatment (equivalent to 36,54 and $72 \mathrm{~kg} / \mathrm{fad}$, respectively ), $40 \%$ of control treatment + Cerealine, $60 \%$ of control treatment + Cerealine, $80 \%$ of control treatment + Cerealine, $40 \%$ of control treatment + Rizobacterine , $60 \%$ of control treatment + Rizobacterine, $80 \%$ of control treatment + Rizobacterine $\}$ were arranged in a sub plot. The sub plot area was $28.80 \mathrm{~m}^{2}$ including 6 ridges of $4-\mathrm{m}$ in length and $120 \mathrm{~cm}$ in width. The phosphorus fertilizer was applied in the form of calcium super phosphate (15\% P2O5) at the rate of $200 \mathrm{~kg} / \mathrm{fad}$ at seed bed preparation. Nitrogen fertilizer was applied for sugar beet as ammonium nitrate at rate of $90 \mathrm{~kg} \mathrm{~N} / \mathrm{fad}$, Potassium fertilizer was added in the form of potassium sulphate $\left(48 \% \mathrm{~K}_{2} \mathrm{O}\right)$ at the rate of $48 \mathrm{~kg} / \mathrm{fad}$ before 
canopy closer. Sowing of sugar beet variety "Geloria" during the $12^{\text {th }}$ of October and faba bean variety "Giza 843" was cultivated in $15^{\text {th }}$ November in both seasons. The cultivation of sugar beet on both sides of the bed with a single plant/hill, the plant density 35,000 plants/fad and planting faba bean on the back of the bed in two lines with two plants / hill. Harvesting of sugar beet was done after 210 days, while faba bean was harvested after 190 days in both seasons. Whereas, the biofertilizers Cerealine and Rhizobecterien were obtained from General Organization for Agricultural Equalization Fund (GOAEF), Agricultural Research Center, Giza, Egypt. Cerealine is the commercial name of nitrogen fixing bacteria containing Azotobcter chroococcum sp. And Azospirillum baseline while, Rhizobecterien is the commercial name of nitrogen fixing bacteria containing Bacillus polymyxa, Both biofertilizers were added at the rate of $10 \mathrm{gm} / \mathrm{kg}$ of faba bean and sugar beet seeds.

Air and soil temperatures were recorded during the two growing seasons as presented in Table 1. Some soil physical properties were analyzed using the procedure described by Black et al. (1965). Soil chemical analysis was determined according to the method of Jackson (1973). Physical and chemical analyses of the soil (the upper $30 \mathrm{~cm}$ ) of the experimental site are given in Table 2.

TABLE 1. Means of some agro meteorological data for Kafer EL-Sheikh area during the two growing seasons.

\begin{tabular}{|l|c|c|c|c|c|c|c|c|c|c|}
\hline \multirow{2}{*}{ Month } & \multicolumn{9}{|c|}{ T(C) } & \multicolumn{2}{c|}{$\begin{array}{c}\text { Ws } \\
\text { m/sec }\end{array}$} & $\begin{array}{c}\text { Pan } \\
\text { Evap. }\end{array}$ & $\begin{array}{c}\text { Rain } \\
\text { mm }\end{array}$ \\
\cline { 2 - 9 } & Max. & Min. & Mean & Max. & Min. & Mean & \multicolumn{7}{|c|}{ 2013/2014 season } \\
\hline Nov. & 25.39 & 15.14 & 20.27 & 87.00 & 64.43 & 75.72 & 0.80 & 2.28 & ----- \\
\hline Dec. & 19.64 & 8.51 & 14.06 & 92.07 & 67.61 & 79.84 & 0.61 & 4.15 & 81.9 \\
\hline Jan. & 20.34 & 7.55 & 13.95 & 93.69 & 70.55 & 80.55 & 0.54 & 1.60 & 20.7 \\
\hline Feb. & 20.64 & 8.19 & 14.42 & 91.90 & 67.15 & 79.53 & 0.79 & 2.52 & 16.5 \\
\hline Mar. & 22.94 & 11.71 & 17.33 & 86.10 & 56.80 & 71.45 & 0.96 & 3.14 & 26.2 \\
\hline April. & 27.50 & 15.53 & 21.52 & 81.80 & 49.80 & 65.8 & 1.07 & 4.91 & 20.2 \\
\hline May & 30.47 & 19.57 & 25.02 & 77.20 & 48.60 & 62.90 & 1.14 & 5.87 & ----- \\
\hline & & & $2014 / 2015$ & season. & & & \\
\hline Nov. & 24.30 & 13.79 & 19.05 & 87.80 & 60.50 & 74.15 & 0.78 & 2.77 & 24.6 \\
\hline Dec. & 22.27 & 9.72 & 16.00 & 88.60 & 63.50 & 76.05 & 0.53 & 1.72 & 5.70 \\
\hline Jan. & 18.79 & 6.46 & 12.63 & 88.10 & 61.10 & 74.60 & 0.82 & 2.70 & 52.55 \\
\hline Feb. & 19.01 & 7.65 & 13.33 & 86.80 & 62.70 & 74.75 & 0.84 & 2.90 & 38.8 \\
\hline Mar. & 22.69 & 11.69 & 17.19 & 82.36 & 58.82 & 70.59 & 1.01 & 3.23 & 15.25 \\
\hline April. & 25.64 & 13.70 & 19.67 & 78.30 & 48.50 & 63.40 & 1.11 & 6.07 & 35.85 \\
\hline May & 30.19 & 18.79 & 24.49 & 77.3 & 46.1 & 61.7 & 1.33 & 7.15 & 0.00 \\
\hline
\end{tabular}

$\mathrm{T}=$ Air temperature, $\mathrm{RH}=$ Relative humidity, Ws = Wind speed and Pan Evap. = pan evaporation Source: Meteorological Station at Sakha Agricultural Research Station $31^{\circ}-07 \mathrm{~N}$ latitude, $30^{\circ}-57 \mathrm{E}$ longitude with an elevation of about 6 meters a above mean sea level.

Egypt. J. Agron. Vol. 38, No.3(2016) 
TABLE 2. Physical and chemical soil characteristics at the experimental sites during 2013-2014 and 2014-2015 seasons.

\begin{tabular}{|l|c|c|c|c|c|}
\hline Soil property & $\mathbf{2 0 1 3 / 2 0 1 4}$ & $\mathbf{2 0 1 4 / 2 0 1 5}$ & Soil property & $\mathbf{2 0 1 3 / 2 0 1 4}$ & $\mathbf{2 0 1 4 / 2 0 1 5}$ \\
\hline $\begin{array}{l}\text { Particle size } \\
\text { distribution }\end{array}$ & 1.45 & 1.55 & Organic Matter \% & 3.40 & 3.41 \\
\hline Coarse sand \% & 16.05 & 14.50 & $\begin{array}{c}\text { Available Nitrogen } \\
\mathrm{mg} / \mathrm{kg} \text { soil }\end{array}$ & 45.0 & 40.90 \\
\hline Fine sand \% & 25.80 & 24.60 & Available $\mathrm{P}_{2} \mathrm{O}_{5} \mathrm{mg} / \mathrm{kg}$ & 6.21 & 5.91 \\
\hline Silt & 57.42 & 59.35 & $\begin{array}{c}\text { Available } \mathrm{K}_{2} \mathrm{O} \mathrm{mg} / \mathrm{kg} \\
\text { soil }\end{array}$ & 334 & 338 \\
\hline Clay & Clay & Clay & pH at $(1: 2.5)$ soil : water & 7.54 & 7.9 \\
\hline Texture class & 1.60 & 1.75 & $\mathrm{EC} \mathrm{dS/m}{ }^{-1}$ & 1.92 & 1.95 \\
\hline CaCo 3 & & & $\begin{array}{c}\text { Soluble Anions } \\
\text { meq/L- }\end{array}$ & & \\
\hline $\begin{array}{l}\text { Soluble cations } \\
\text { meq/L- }\end{array}$ & 1.50 & 1.14 & SO4= & 1.39 & 0.89 \\
\hline $\mathrm{K}+$ & 0.80 & 0.76 & $\mathrm{Cl}-$ & 2.1 & 1.80 \\
\hline $\mathrm{Na}+$ & 1.20 & 0.90 & $\mathrm{HCO}-$ & 0.90 & 0.86 \\
\hline $\mathrm{Mg}++$ & 0.89 & 0.75 & $\mathrm{CO}=$ & - & - \\
\hline $\mathrm{Ca}++$ & & & & & \\
\hline
\end{tabular}

The recorded data

Sugar beet characters

Vegetative characters: Number of leaf/plant, fresh leaf weight/plant, root length $(\mathrm{cm})$, diameter $(\mathrm{cm})$, Root fresh weight $(\mathrm{g} / \mathrm{plant})$, leaf dry weight/plant, root dry weight/plant and total dry weight/plant.

Yield characters : At harvest, guarded plants of six ridges were uprooted, topped and weighted to determine the following parameters: root yield $\left(\right.$ ton $\left.\mathrm{fad}^{-1}\right)$ and sugar yield $\left(\right.$ ton $\left.\mathrm{fad}^{-1}\right)$.

Quality and chemical constituents: Sucrose percentage was estimated in fresh samples of sugar beet roots, using Saccharometer according to the method described in A.O.A.C. (1990), Total soluble solids (TSS \%) was determined by using the hand refractometer. Sodium, potassium and Purity percent: The purity of a sugar solution may be defined as the percentage of total solids (dry substance) of all solution which is sugar.

Faba bean characters

Plant height $(\mathrm{cm})$, number of branches/plant, number of pods/plant, number of seeds/plant, 100-seed weight $(\mathrm{g})$, seed yield/plant, straw yield $\left(\right.$ ton $\left.\mathrm{fad}^{-1}\right)$ and seed yield/fad (ton $\left.\mathrm{fad}^{-1}\right)$.

The Data obtained were statistically analyzed according to the method described by Gomez \& Gomez (1984). Means of the treatments were compared by the least significant difference (LSD) at $5 \%$ level of significance which 
developed by Waller \& Duncan (1969). All statistical analysis was perforrmed using analysis of variance technique of (MSTATC) computer software package.

\section{Land equivalent ratio (LER)}

LER was described by Willey \& Osiru (1972). Land equivalent ration LER was determined according to the following formula:

$$
\mathrm{LER}=\frac{Y a b}{Y a a}+\frac{Y b a}{Y b b}
$$

where: Yaa and Ybb were pure stand of crop a and b respectively, Yab is yield of the intetcropped a crop (ton /fad), Yba is yield of the intercropped b crop ( ton /fad).

\section{Total return of intercropping cultures (Net income/fad)}

It was calculated for each treatment in price of faba bean yield by Egyptian pounds + price of sugar beet yield by Egyptian pounds, using the average farm gate price for two seasons. The market price for faba bean seeds and sugar beet was LE 900 / ardab and LE 375 /ton, respectively.

\section{Results and Discussion}

\section{Faba bean characters}

Plant height, number of branches/ plant, number of pods /plant, number of seeds/plant, weight of 100 seeds, straw yield $\mathrm{fad}^{-1}$, seeds yield $\mathrm{fad}^{-1}$, and protein content of faba bean as affected by sowing distance and the combination between mineral nitrogen levels and bio fertilizers (Cerealine and Rizobacterin) in 2013/2014 and 2014/2015 seasons are presented in Tables 3 and 4 .

The data in both seasons showed that increasing faba bean sowing distance from 10 to $30 \mathrm{~cm}$ resulted in a significant increase at all previous mentioned agronomic traits except the plant height and straw yield/fad traits in both seasons which recorded decreasing with increasing the bean sowing distance. A significant increase in these traits was accompanied with each increment of plant density. The data revealed that the planting space of $30 \mathrm{~cm}$ gave the greatest values at all previous mentioned growth traits in both seasons except the plant height and straw yield/fad characters which recorded the lowest values, while the planting space of $10 \mathrm{~cm}$ recorded the lowest values in all previous characters except the plant height and straw yield/fad which showed the highest values. Such effect of faba bean sowing distance could be attributed mainly to its role in the growth stages and the competition between all plants on nutrition and light and the effect of various physiological process including cell division and cell elongation of internodes resulting in more tillers formation, leaf numbers and photosynthetic area (leaf area), which resulted in more photosynthetic production. These results are in harmony with those obtained by Hussein \& EL-Deeb (1999) and Mohammed et al. (2005).

Egypt. J. Agron. Vol. 38, No.3(2016) 
TABLE 3. Plant height (cm), number of branches/plant ,number of pods/plant and number of seeds/plant of faba bean (Vicia faba $L$.) as affected by bean sowing distance and combinations between mineral nitrogen levels and bio fertilizers (Cerealine and Rizobacterin) and their interaction during 2013/2014 and 2014/2015seasons .

\begin{tabular}{|c|c|c|c|c|c|c|c|c|}
\hline \multirow{2}{*}{\begin{tabular}{|l}
\multicolumn{1}{|c}{ Factors } \\
$\begin{array}{l}\text { Bean sowing } \\
\text { distance }\end{array}$
\end{tabular}} & \multicolumn{2}{|c|}{ Plant height (cm) } & \multicolumn{2}{|c|}{$\begin{array}{c}\text { No. of } \\
\text { branch/plant }\end{array}$} & \multicolumn{2}{|c|}{$\begin{array}{c}\text { No. of } \\
\text { pods/plant }\end{array}$} & \multicolumn{2}{|c|}{$\begin{array}{c}\text { No. of } \\
\text { seeds/plant }\end{array}$} \\
\hline & $2013 / 14$ & 2014/15 & $\begin{array}{c}2013 / \\
14\end{array}$ & 2014/15 & $2013 / 14$ & 2014/15 & $2013 / 14$ & $2014 / 15$ \\
\hline $10 \mathrm{~cm}$ & 119.84 & 120.19 & 2.33 & 2.17 & 13.41 & 13.26 & 40.09 & 39.92 \\
\hline $20 \mathrm{~cm}$ & 115.79 & 115.15 & 2.92 & 2.77 & 14.52 & 14.36 & 41.84 & 41.63 \\
\hline $30 \mathrm{~cm}$ & 110.40 & 109.77 & 3.85 & 3.74 & 15.25 & 15.10 & 43.27 & 43.14 \\
\hline LSD & 3.95 & 3.92 & 0.34 & 0.36 & 0.79 & 0.74 & 0.83 & 0.91 \\
\hline \multicolumn{9}{|l|}{$\begin{array}{l}\text { Fertilizer treat. } \\
\text { (kg/fad) }\end{array}$} \\
\hline $\begin{array}{l}90 \mathrm{~kg} \mathrm{~N} / \mathrm{fad} \\
\text { (Control) }\end{array}$ & 116.18 & 115.03 & 3.02 & 2.92 & 14.39 & 14.23 & 41.96 & 41.78 \\
\hline $36 \mathrm{~kg} \mathrm{~N} / \mathrm{fad}$ & 112.72 & 110.10 & 2.95 & 2.82 & 14.18 & 14.02 & 41.01 & 41.15 \\
\hline $36 \mathrm{~kg} \mathrm{~N} / \mathrm{fad}+\mathrm{C}$ & 113.50 & 112.82 & 2.98 & 2.85 & 14.20 & 14.05 & 41.20 & 41.16 \\
\hline $36 \mathrm{~kg} \mathrm{~N} / \mathrm{fad}+\mathrm{R}$ & 113.51 & 112.83 & 3.00 & 2.86 & 14.26 & 14.10 & 41.16 & 41.18 \\
\hline $54 \mathrm{~kg} \mathrm{~N} / \mathrm{fad}$ & 115.05 & 114.45 & 3.01 & 2.87 & 14.48 & 14.32 & 41.72 & 41.56 \\
\hline $54 \mathrm{~kg} \mathrm{~N} / \mathrm{fad}+\mathrm{C}$ & 116.17 & 115.25 & 3.04 & 2.89 & 14.42 & 14.26 & 41.78 & 41.64 \\
\hline $54 \mathrm{~kg} \mathrm{~N} / \mathrm{fad}+\mathrm{R}$ & 115.34 & 115.25 & 3.04 & 2.89 & 14.39 & 14.24 & 41.64 & 41.494 \\
\hline $72 \mathrm{~kg} \mathrm{~N} / \mathrm{fad}$ & 117.00 & 116.35 & 3.06 & 2.92 & 14.50 & 14.35 & 41.97 & 41.80 \\
\hline $72 \mathrm{~kg} \mathrm{~N} / \mathrm{fad}+\mathrm{C}$ & 118.13 & 117.16 & 3.07 & 2.95 & 14.52 & 14.37 & 42.09 & 41.94 \\
\hline $72 \mathrm{~kg} \mathrm{~N} / \mathrm{fad}+\mathrm{R}$ & 118.14 & 117.16 & 3.10 & 2.98 & 14.58 & 14.43 & 42.28 & 42.08 \\
\hline LSD & 1.40 & 1.10 & N.S & 0.095 & 0.151 & 0.141 & 0.229 & 0.196 \\
\hline Interaction & N.S & N.S & 0.686 & N.S & 0.258 & N.S & N.S & N.S \\
\hline
\end{tabular}

$\mathrm{N}=$ nitrogen, $\mathrm{C}=$ Cerealine, $\mathrm{R}=$ Rizobacterin, $\mathrm{LSD}=$ least significant difference and Ns indicate $\mathrm{p}<0.05$ and not significant, respectively. 
TABLE 4. Weight of 100 seeds (gm), Straw yield (ton /fad), seeds yield (ton fad ${ }^{-1}$ ) and protein percent of faba bean (Vicia faba $L$.) as affected by faba bean sowing distance and combinations between mineral nitrogen levels and bio fertilizers (Cerealine and Rizobacterin) and their interaction during 2013/2014 and 2014/2015 seasons .

\begin{tabular}{|c|c|c|c|c|c|c|c|c|}
\hline \multirow{2}{*}{$\begin{array}{l}\text { Factors } \\
\text { Bean } \\
\text { sowing }\end{array}$} & \multicolumn{2}{|c|}{$\begin{array}{c}\text { Weight of } 100 \\
\text { seed(gm) }\end{array}$} & \multicolumn{2}{|c|}{$\begin{array}{l}\text { Straw yield/fad } \\
\left(\text { ton fad }^{-1}\right)\end{array}$} & \multicolumn{2}{|c|}{$\begin{array}{l}\text { Seeds yield/fad } \\
\left(\text { ton fad }^{-1}\right)\end{array}$} & \multicolumn{2}{|c|}{ Protein percent } \\
\hline & 2013/14 & 2014/15 & 2013/14 & $2014 / 15$ & 2013/14 & $2014 / 15$ & 2013/14 & $2014 / 15$ \\
\hline $10 \mathrm{~cm}$ & 53.910 & 53.77 & 1.322 & 1.179 & 0.929 & 0.76 & 20.112 & 19.918 \\
\hline $20 \mathrm{~cm}$ & 56.547 & 56.220 & 1.220 & 1.064 & 1.022 & 0.84 & 20.941 & 20.667 \\
\hline $30 \mathrm{~cm}$ & 59.364 & 58.743 & 1.063 & 0.953 & 1.072 & 0.88 & 21.721 & 21.571 \\
\hline LSD & 2.052 & 1.470 & 1.174 & 0.049 & 0.072 & 0.117 & 0.279 & 0.0866 \\
\hline \multicolumn{9}{|l|}{$\begin{array}{l}\text { Fertilizer } \\
\text { treatment }\end{array}$} \\
\hline $\begin{array}{l}90 \mathrm{~kg} \mathrm{~N} \\
\text { fad }^{-1} \\
(\text { Control) }\end{array}$ & 65.600 & 56.240 & 1.211 & 1.060 & 1.12 & 0.93 & 20.920 & 20.710 \\
\hline $\begin{array}{l}72 \mathrm{~kg} \mathrm{~N} \\
\text { fad }^{-1}\end{array}$ & 55.788 & 55.334 & 1.197 & 1.111 & 0.85 & 0.68 & 20.245 & 19.867 \\
\hline $\begin{array}{l}54 \mathrm{~kg} \mathrm{~N} \\
\mathrm{fad}^{-1}\end{array}$ & 55.921 & 55.376 & 1.193 & 1.098 & 0.88 & 0.71 & 20.572 & 20.221 \\
\hline $\begin{array}{l}36 \mathrm{~kg} \mathrm{~N} \\
\mathrm{fad}^{-1}\end{array}$ & 56.047 & 55.552 & 1.194 & 1.082 & 0.89 & 0.73 & 20.688 & 20.354 \\
\hline $\begin{array}{l}72 \mathrm{~kg} \mathrm{~N} \\
\text { fad }^{-1}+C\end{array}$ & 56.574 & 55.695 & 1.185 & 1.065 & 0.98 & 0.83 & 20.772 & 20.491 \\
\hline $\begin{array}{l}54 \mathrm{~kg} \mathrm{~N} \\
\mathrm{fad}^{-1}+\mathrm{C}\end{array}$ & 56.710 & 56.535 & 1.184 & 1.060 & 1.03 & 0.84 & 20.921 & 20.596 \\
\hline $\begin{array}{l}36 \mathrm{~kg} \mathrm{~N} \\
\mathrm{fad}^{-1}+\mathrm{C}\end{array}$ & 56.876 & 56.685 & 1.195 & 1.054 & 1.06 & 0.86 & 21.401 & 20.788 \\
\hline $\begin{array}{l}72 \mathrm{~kg} \mathrm{~N} \\
\mathrm{fad}^{-1}+\mathrm{R}\end{array}$ & 56.900 & 56.866 & 1.193 & 1.048 & 1.04 & 0.86 & 21.276 & 21.240 \\
\hline $\begin{array}{l}54 \mathrm{~kg} \mathrm{~N} \\
\mathrm{fad}^{-1}+\mathrm{R}\end{array}$ & 57.035 & 57.011 & 1.186 & 1.037 & 1.10 & 0.92 & 21.336 & 21.288 \\
\hline $\begin{array}{l}36 \mathrm{~kg} \mathrm{~N} \\
\mathrm{fad}^{-1}+\mathrm{R}\end{array}$ & 57.566 & 57.201 & 1.174 & 1.032 & 1.12 & 0.93 & 21.401 & 21.625 \\
\hline LSD & 0.155 & 1.355 & N.S & N.S & 0.053 & 0.061 & 0.303 & 0.122 \\
\hline Interaction & 0.276 & N.S & N.S & N.S & 0.466 & 0.495 & N.S & 0.789 \\
\hline
\end{tabular}

$\mathrm{N}=$ nitrogen, $\mathrm{C}=$ Cerealine, $\mathrm{R}=$ Rizobacterin, $\mathrm{LSD}=$ least significant difference and Ns indicate $\mathrm{p}<0.05$ and not significant, respectively.

The application of combination between mineral nitrogen levels and bio fertilizers (Cerealine and Rizobacterin) resulted in a significant effects in plant height, number of pods /plant, number of seeds/plant, weight of 100 seeds, seeds yield/fad and protein Egypt. J. Agron. Vol. 38, No.3(2016) 
content in both seasons and number of branches/ plant in the second season only, however the straw yield/fad did not significantly differed in both seasons. The treatment of $36 \mathrm{~kg}$ mineral nitrogen level showed the lowest values at plant height $(\mathrm{cm})$, number of pods/plant, number of seeds/plant, weight of 100 seeds (gm), seeds yield $\left(\right.$ ton $\mathrm{fad}^{-1}$ ) and protein percent of faba bean in the two growing seasons and number of branches/plant in the second season, while the treatments of $90 \mathrm{~kg}$ mineral nitrogen as individual and $72 \mathrm{~kg}$ mineral nitrogen as individual or in combination with Cerealine or Rizobacterien recorded the highest significant values compared with the other combinations at plant height $(\mathrm{cm})$, number of pods /plant, number of seeds/plant, weight of 100 seeds, seeds yield/fad and protein content in both seasons and number of branches/ plant in the second season, on the other hand the treatment of $54 \mathrm{~kg}$ mineral nitrogen as individual and in combination with Cerealine or Rizobacterien showed relative increasing at all previous significantly traits compared with the level of $36 \mathrm{~kg}$ mineral nitrogen which recorded the lowest values. Such effect of fertilizers might have been resulted from the role of Nitrogen fertilizers in enhancing the soil biological activity which improved nutrient mobilization from organic to chemical fertilizers which is closely related to the amount of absorbed nitrogen and then improve translocation of assimilates and thus improve the growth characters.

With regard to the interaction faba bean sowing distance and combinations between mineral nitrogen levels and bio fertilizers (Cerealine and Rizobacterin), the data in Tables 3 and 4 show that there is a significant effect on number of branch/ plant, number of pods /plant, weight of 100 seeds in the first season and protein content in the second season while the seed yield/fad had a significant effect in both. Similar results were obtained by Mahmoud et al. (2014).

\section{Sugar beet crop characters}

Results in Tables $5,6,7$ and 8 show that faba bean sowing distance and the combination between mineral nitrogen levels and bio fertilizers (Cerealine and Rizobacterin) and its interaction had a significant effect on the number of leaves / plant, root length $(\mathrm{cm})$, root diameter $(\mathrm{cm})$, fresh leaves weight/plant, fresh root weight/plant, dry leaves weight /plant, dry root weight /plant, root yield/fad (ton fad $\left.{ }^{-1}\right)$, sugars percent (\%), purity percent and TSS (\%) of sugar beet in 2013/2014 and 2014/2015 seasons.

There are significant differences in number of leaves /plant, root length $(\mathrm{cm})$, root diameter $(\mathrm{cm})$, fresh leaves weight/plant, fresh root weight/plant, dry leaves weight / plant, dry root weight /plant, root yield/fad(ton fad $\left.{ }^{-1}\right)$, sugars percent (\%), purity percent and TSS (\%) due to the application of combination between mineral nitrogen levels and bio fertilizers (Cerealine and Rizobacterin) in both seasons. The treatments of $90 \mathrm{~kg}$ mineral nitrogen as individual and $72 \mathrm{~kg}$ mineral nitrogen as individual or in combination with Cerealine or Rizobacterien showed the highest significant values compared with the other combinations for the previous traits, followed by the treatments of $54 \mathrm{~kg}$ mineral nitrogen as 
individual and in combination with Cerealine or Rizobacterien. However, the lowest values were obtained from the application of $36 \mathrm{~kg} \mathrm{Nfad}^{-1}$ as individual or in combination with Cerealine or Rizobacterien. Such effect of fertilizers might have been resulted from the role of fertilizers in enhancing the soil biological activity which improved nutrient mobilization from organic and chemical fertilizers which is closely related to the amount of absorbed nitrogen and then improve translocation of assimilates and thus improve the growth characters. These results are in harmony with those obtained by Abdel Motagally et al. (2014).

TABLE 5. Number of leaves /plant, root length and root diameter of sugar beet (Beta vulgaris) as affected by bean sowing distance and combinations between mineral nitrogen levels and bio fertilizers (Cerealine and Rizobacterin) and their interaction during 2013/2014 and 2014/2015 seasons .

\begin{tabular}{|c|c|c|c|c|c|c|}
\hline \multirow{2}{*}{$\begin{array}{l}\text { Factors } \\
\text { Bean sowing } \\
\text { distance }\end{array}$} & \multicolumn{2}{|c|}{ No. of leaves/plant } & \multicolumn{2}{|c|}{ Root length (cm) } & \multicolumn{2}{|c|}{ Root diameter $(\mathbf{c m})$} \\
\hline & 2013/14 & $2014 / 15$ & 2013/14 & 2014/15 & 2013/14 & $2014 / 15$ \\
\hline $10 \mathrm{~cm}$ & 23.37 & 24.11 & 23.53 & 23.54 & 13.37 & 13.12 \\
\hline $20 \mathrm{~cm}$ & 24.23 & 25.70 & 22.30 & 22.26 & 14.06 & 13.63 \\
\hline $30 \mathrm{~cm}$ & 25.92 & 25.93 & 21.29 & 21.00 & 14.57 & 14.43 \\
\hline LSD & 0.979 & N.S & 0.709 & 0.363 & 0.651 & 0.522 \\
\hline \multicolumn{7}{|c|}{ Fertilizer treatment } \\
\hline $\begin{array}{l}90 \mathrm{~kg} \mathrm{~N} \text { fad }^{-1} \\
\text { (Control) }\end{array}$ & 29.51 & 28.24 & 22.37 & 22.27 & 13.82 & 13.72 \\
\hline $72 \mathrm{~kg} \mathrm{~N} \mathrm{fad}^{-1}$ & 24.75 & 25.96 & 22.06 & 21.42 & 13.08 & 13.50 \\
\hline $54 \mathrm{~kg} \mathrm{~N} \mathrm{fad}^{-1}$ & 24.86 & 26.97 & 22.06 & 21.67 & 13.11 & 13.52 \\
\hline $36 \mathrm{~kg} \mathrm{~N} \mathrm{fad}^{-1}$ & 24.78 & 26.01 & 22.02 & 22.24 & 13.17 & 13.60 \\
\hline $72 \mathrm{~kg} \mathrm{~N} \mathrm{fad}^{-1}+\mathrm{C}$ & 24.83 & 27.74 & 22.10 & 22.23 & 13.97 & 13.70 \\
\hline $54 \mathrm{~kg} \mathrm{~N} \mathrm{fad}^{-1}+\mathrm{C}$ & 26.87 & 28.79 & 22.46 & 22.08 & 13.96 & 13.72 \\
\hline $36 \mathrm{~kg} \mathrm{~N} \mathrm{fad}^{-1}+\mathrm{C}$ & 25.81 & 28.35 & 22.79 & 22.42 & 14.04 & 13.78 \\
\hline $72 \mathrm{~kg} \mathrm{~N} \mathrm{fad}^{-1}+\mathrm{R}$ & 28.88 & 29.90 & 22.62 & 22.90 & 14.99 & 13.87 \\
\hline $54 \mathrm{~kg} \mathrm{~N} \mathrm{fad}^{-1}+\mathrm{R}$ & 30.99 & 28.87 & 22.65 & 22.94 & 14.93 & 13.89 \\
\hline $36 \mathrm{~kg} \mathrm{~N} \mathrm{fad}^{-1}+\mathrm{R}$ & 27.90 & 28.96 & 22.58 & 22.49 & 14.94 & 13.90 \\
\hline LSD & 0.349 & 1.371 & 0.415 & 0.288 & 0.219 & 0.126 \\
\hline Interaction & 0.172 & N.S & N.S & N.S & N.S & N.S \\
\hline
\end{tabular}

$\mathrm{N}=$ nitrogen, $\mathrm{C}=$ Cerealine, $\mathrm{R}=$ Rizobacterin, $\mathrm{LSD}=$ least significant difference and Ns indicate $\mathrm{p}<0.05$, and not significant, respectively.

Egypt. J. Agron. Vol. 38, No.3(2016) 
TABLE 6. Fresh leaves weight (gm)/plant, fresh root weight/plant, dry leaves weight / plant and dry root weight / plant of sugar beet (Beta vulgaris) as affected by bean sowing distance and combinations between mineral nitrogen levels and bio fertilizers (Cerealine and Rizobacterin) and their interaction during 2013/2014 and 2014/2015 seasons .

\begin{tabular}{|c|c|c|c|c|c|c|c|c|}
\hline \multirow{2}{*}{$\begin{array}{l}\text { Factors } \\
\text { Bean } \\
\text { sowing } \\
\text { distance }\end{array}$} & \multicolumn{2}{|c|}{$\begin{array}{c}\text { Fresh } \\
\text { leaves } \\
\text { weight } \\
\text { (gm)/plant }\end{array}$} & \multicolumn{2}{|c|}{$\begin{array}{c}\text { Fresh root } \\
\text { weight } \\
\text { (gm)/ plant }\end{array}$} & \multicolumn{2}{|c|}{$\begin{array}{l}\text { Dry leaves } \\
\text { weight } \\
(\mathrm{gm}) / \text { plant }\end{array}$} & \multicolumn{2}{|c|}{$\begin{array}{c}\text { Dry root } \\
\text { weight } \\
\text { (gm) / plant }\end{array}$} \\
\hline & 2013/14 & $2014 / 15$ & 2013/14 & $2014 / 15$ & $2013 / 14$ & 2014/15 & 2013/14 & $2014 / 15$ \\
\hline $10 \mathrm{~cm}$ & 492.32 & 571.70 & 647.79 & 647.75 & 151.64 & 150.78 & 399.46 & 396.06 \\
\hline $20 \mathrm{~cm}$ & 516.00 & 575.17 & 742.00 & 741.84 & 155.61 & 155.22 & 408.65 & 407.10 \\
\hline $30 \mathrm{~cm}$ & 597.79 & 579.70 & 766.32 & 765.93 & 158.35 & 158.91 & 414.29 & 413.54 \\
\hline LSD & 27.49 & 47.84 & 27.49 & 27.60 & 1.17 & 2.16 & 6.61 & 4.78 \\
\hline \multicolumn{9}{|l|}{ Fertilizer } \\
\hline $\begin{array}{l}90 \mathrm{~kg} \mathrm{~N} \mathrm{fad}^{-1} \\
\text { (Control) }\end{array}$ & 535.37 & 595.51 & 718.70 & 718.50 & 155.20 & 155.00 & 409.47 & 407.56 \\
\hline $72 \mathrm{~kg} \mathrm{~N} \mathrm{fad}^{-1}$ & 484.79 & 561.70 & 700.57 & 700.57 & 153.3 & 153.55 & 394.47 & 394.01 \\
\hline $54 \mathrm{~kg} \mathrm{~N} \mathrm{fad}^{-1}$ & 490.31 & 567.41 & 707.17 & 707.17 & 154.2 & 154.89 & 397.14 & 395.11 \\
\hline $36 \mathrm{~kg} \mathrm{~N} \mathrm{fad}^{-1}$ & 490.64 & 568.54 & 713.55 & 713.55 & 154.0 & 154.80 & 401.18 & 395.36 \\
\hline $72 \mathrm{~kg} \mathrm{~N} \mathrm{fad}^{-1}+\mathrm{C}$ & 497.71 & 573.21 & 714.18 & 713.67 & 155.4 & 154.54 & 405.59 & 406.82 \\
\hline $54 \mathrm{~kg} \mathrm{~N} \mathrm{fad}^{-1}+\mathrm{C}$ & 503.95 & 574.64 & 720.63 & 720.62 & 155.5 & 155.12 & 407.81 & 405.94 \\
\hline $36 \mathrm{~kg} \mathrm{~N} \mathrm{fad}^{-1}+\mathrm{C}$ & 504.49 & 577.11 & 721.30 & 721.16 & 155.6 & 155.80 & 412.90 & 408.20 \\
\hline $72 \mathrm{~kg} \mathrm{~N} \mathrm{fad}^{-1}+\mathrm{R}$ & 517.12 & 572.10 & 727.46 & 727.46 & 156.2 & 156.22 & 414.57 & 413.37 \\
\hline $54 \mathrm{~kg} \mathrm{~N} \mathrm{fad}^{-1}+\mathrm{R}$ & 511.79 & 575.80 & 728.08 & 728.06 & 156.0 & 156.56 & 415.67 & 414.51 \\
\hline $36 \mathrm{~kg} \mathrm{~N} \mathrm{fad}^{-1}+\mathrm{R}$ & 517.52 & 589.16 & 734.37 & 734.31 & 156.8 & 156.24 & 415.88 & 414.76 \\
\hline LSD & 10.60 & 18.24 & 10.602 & 10.578 & 0.84 & 1.35 & 3.73 & 1.77 \\
\hline Interaction & 14.60 & N.S & 16.945 & N.S & N.S & N.S & 1.27 & N.S \\
\hline
\end{tabular}

$\mathrm{N}=$ nitrogen, $\mathrm{C}=$ Cerealine, $\mathrm{R}=$ Rizobacterin, $\mathrm{LSD}=$ least significant difference and Ns indicate $\mathrm{p}<0.05$ and not significant, respectively. 
TABLE 7. Root yield ton fad ${ }^{-1}$, sugar percent $\%$, purity $\%$ and TSS $\%$ of sugar beet as affected by bean sowing distance and combinations between mineral nitrogen levels and bio fertilizers (Cerealine and Rizobacterin) and their interaction during 2013/2014 and 2014/2015 seasons .

\begin{tabular}{|c|c|c|c|c|c|c|c|c|}
\hline \multirow{2}{*}{$\begin{array}{l}\text { Factors } \\
\begin{array}{l}\text { Bean sowing } \\
\text { distance }\end{array}\end{array}$} & \multicolumn{2}{|c|}{ Root yield ton fad ${ }^{-1}$} & \multicolumn{2}{|c|}{ Sugar percent $\%$} & \multicolumn{2}{|c|}{ Purity\% } & \multicolumn{2}{|c|}{ TSS \% } \\
\hline & 2013/14 & $2014 / 15$ & 2013/14 & $2014 / 15$ & 2013/14 & $2014 / 15$ & 2013/14 & $2014 / 15$ \\
\hline $10 \mathrm{~cm}$ & 14.45 & 13.76 & 15.18 & 15.08 & 81.0 & 81.1 & 18.39 & 18.31 \\
\hline $20 \mathrm{~cm}$ & 19.41 & 18.84 & 14.50 & 14.29 & 79.9 & 80.0 & 17.47 & 17.25 \\
\hline $30 \mathrm{~cm}$ & 20.54 & 20.05 & 13.04 & 12.96 & 79.3 & 79.1 & 16.60 & 16.30 \\
\hline LSD & 4.893 & 5.0301 & 0.427 & 0.237 & 0.64 & 0.37 & 0.542 & 0.115 \\
\hline \multicolumn{9}{|l|}{$\begin{array}{l}\text { Fertilizer } \\
\text { treatment } \\
(\mathbf{k g} / \mathbf{f a d})\end{array}$} \\
\hline $\begin{array}{l}90 \mathrm{~kg} \mathrm{~N} \mathrm{fad}^{-1} \\
\text { (Control) }\end{array}$ & 21.83 & 21.34 & 14.24 & 14.41 & 80.1 & 80.0 & 17.68 & 17.59 \\
\hline $72 \mathrm{~kg} \mathrm{~N} \mathrm{fad}^{-1}$ & 13.96 & 13.29 & 13.76 & 13.86 & 78.6 & 78.4 & 16.96 & 17.21 \\
\hline $54 \mathrm{~kg} \mathrm{~N} \mathrm{fad}^{-1}$ & 13.72 & 12.68 & 13.85 & 13.96 & 78.4 & 78.7 & 17.42 & 17.22 \\
\hline $36 \mathrm{~kg} \mathrm{~N} \mathrm{fad}^{-1}$ & 13.96 & 13.29 & 13.95 & 13.91 & 78.7 & 78.2 & 17.42 & 17.22 \\
\hline $72 \mathrm{~kg} \mathrm{~N} \mathrm{fad}^{-1}+\mathrm{C}$ & 15.71 & 15.31 & 14.13 & 14.18 & 80.7 & 80.5 & 17.43 & 17.29 \\
\hline $54 \mathrm{~kg} \mathrm{~N} \mathrm{fad}^{-1}+\mathrm{C}$ & 19.95 & 19.49 & 14.19 & 14.16 & 80.5 & 80.5 & 17.65 & 17.46 \\
\hline $36 \mathrm{~kg} \mathrm{~N} \mathrm{fad}^{-1}+\mathrm{C}$ & 13.72 & 12.68 & 14.28 & 14.11 & 80.5 & 80.5 & 17.67 & 17.33 \\
\hline $72 \mathrm{~kg} \mathrm{~N} \mathrm{fad}^{-1}+\mathrm{R}$ & 19.89 & 19.63 & 14.49 & 14.37 & 81.2 & 81.3 & 17.68 & 17.69 \\
\hline $54 \mathrm{~kg} \mathrm{~N} \mathrm{fad}^{-1}+\mathrm{R}$ & 21.36 & 20.87 & 14.47 & 14.45 & 81.1 & 81.2 & 17.76 & 16.94 \\
\hline $36 \mathrm{~kg} \mathrm{~N} \mathrm{fad}^{-1}+\mathrm{R}$ & 21.66 & 21.18 & 14.33 & 14.50 & 81.0 & 81.1 & 17. 62 & 16.92 \\
\hline LSD & 0.380 & 0.396 & 0.177 & 0.127 & 0.995 & 0.985 & 0.354 & 0.242 \\
\hline Interaction & 0.682 & 0.572 & N.S & N.S & N.S & N.S & N.S & 0.572 \\
\hline
\end{tabular}

$\mathrm{N}=$ nitrogen, $\mathrm{C}=$ Cerealine, $\mathrm{R}=$ Rizobacterin, $\mathrm{LSD}=$ least significant difference and Ns indicate $\mathrm{p}<0.05$ and not significant, respectively.

Egypt. J. Agron. Vol. 38, No.3(2016) 
EFFECT OF FABA BEAN SOWING DISTANCE AND SOME ...

TABLE 8. Roots yield fad $^{-1}$ of sugar beet (Beta vulgaris) and seed yield fad ${ }^{-1}$ of faba bean (Vicia faba $L$.) as affected by the interaction between faba bean sowing distance and combinations between mineral nitrogen levels and bio fertilizers (Cerealine and Rizobacterin) during 2013/2014 and 2014/2015 seasons.

\begin{tabular}{|c|c|c|c|c|c|}
\hline \multirow{2}{*}{\multicolumn{2}{|c|}{$\begin{array}{l}\text { Combinations of mineral } \mathrm{N} \text { and } \\
\text { bio fertilizers }\end{array}$}} & \multicolumn{2}{|c|}{ Root yield ton fad $^{-1}$} & \multicolumn{2}{|c|}{$\begin{array}{c}\text { Faba bean Seed yield ton } \\
\text { fad }^{-1}\end{array}$} \\
\hline & & $2013 / 2014$ & $2014 / 2015$ & $2013 / 2014$ & $2014 / 2015$ \\
\hline $90 \mathrm{~kg} \mathrm{~N} \mathrm{fad}^{-1}$ (Control) & \multirow{10}{*}{$10 \mathrm{~cm}$} & 15.78 & 15.37 & 1.00 & 0.84 \\
\hline $72 \mathrm{~kg} \mathrm{~N} \mathrm{fad}^{-1}$ & & 15.45 & 14.94 & 0.98 & 0.82 \\
\hline $54 \mathrm{~kg} \mathrm{~N} \mathrm{fad}^{-1}$ & & 15.04 & 14.5 & 0.93 & 0.79 \\
\hline $36 \mathrm{~kg} \mathrm{~N} \mathrm{fad}^{-1}$ & & 11.69 & 10.02 & 0.81 & 0.62 \\
\hline $72 \mathrm{~kg} \mathrm{~N} \mathrm{fad}^{-1}+\mathrm{C}$ & & 15.58 & 15.09 & 0.99 & 0.82 \\
\hline $54 \mathrm{~kg} \mathrm{~N} \mathrm{fad}^{-1}+\mathrm{C}$ & & 15.38 & 14.62 & 0.96 & 0.80 \\
\hline $36 \mathrm{~kg} \mathrm{~N} \mathrm{fad}^{-1}+\mathrm{C}$ & & 12.00 & 11.40 & 0.82 & 0.64 \\
\hline $72 \mathrm{~kg} \mathrm{~N} \mathrm{fad}^{-1}+\mathrm{R}$ & & 15.74 & 15.29 & 0.99 & 0.84 \\
\hline $54 \mathrm{~kg} \mathrm{~N} \mathrm{fad}^{-1}+\mathrm{R}$ & & 15.43 & 14.64 & 0.97 & 0.81 \\
\hline $36 \mathrm{~kg} \mathrm{~N} \mathrm{fad}^{-1}+\mathrm{R}$ & & 12.37 & 11.70 & 0.84 & 0.64 \\
\hline $90 \mathrm{~kg} \mathrm{~N}$ fad $^{-1}$ (Control) & \multirow{10}{*}{$20 \mathrm{~cm}$} & 24.36 & 23.81 & 1.16 & 0.97 \\
\hline $72 \mathrm{~kg} \mathrm{~N} \mathrm{fad}^{-1}$ & & 21.00 & 21.16 & 1.01 & 0.85 \\
\hline $54 \mathrm{~kg} \mathrm{~N} \mathrm{fad}^{-1}$ & & 15.85 & 15.53 & 1.00 & 0.84 \\
\hline $36 \mathrm{~kg} \mathrm{~N} \mathrm{fad}^{-1}$ & & 12.88 & 12.06 & 0.84 & 0.65 \\
\hline $72 \mathrm{~kg} \mathrm{~N} \mathrm{fad}^{-1}+\mathrm{C}$ & & 23.39 & 22.91 & 1.14 & 0.96 \\
\hline $54 \mathrm{~kg} \mathrm{~N} \mathrm{fad}^{-1}+\mathrm{C}$ & & 21.87 & 21.59 & 1.02 & 0.86 \\
\hline $36 \mathrm{~kg} \mathrm{~N} \mathrm{fad}^{-1}+\mathrm{C}$ & & 14.24 & 12.44 & 0.90 & 0.72 \\
\hline $72 \mathrm{~kg} \mathrm{~N} \mathrm{fad}^{-1}+\mathrm{R}$ & & 23.63 & 23.14 & 1.15 & 0.96 \\
\hline $54 \mathrm{~kg} \mathrm{~N} \mathrm{fad}^{-1}+\mathrm{R}$ & & 22.29 & 21.90 & 1.09 & 0.86 \\
\hline $36 \mathrm{~kg} \mathrm{~N} \mathrm{fad}^{-1}+\mathrm{R}$ & & 14.59 & 13.88 & 0.91 & 0.76 \\
\hline $90 \mathrm{~kg} \mathrm{~N}$ fad $^{-1}$ (Control) & \multirow{10}{*}{$30 \mathrm{~cm}$} & 25.35 & 24.85 & 1.20 & 0.98 \\
\hline $72 \mathrm{~kg} \mathrm{~N} \mathrm{fad}^{-1}$ & & 23.21 & 22.80 & 1.14 & 0.91 \\
\hline $54 \mathrm{~kg} \mathrm{~N} \mathrm{fad}^{-1}$ & & 16.25 & 15.90 & 1.01 & 0.85 \\
\hline $36 \mathrm{~kg} \mathrm{~N} \mathrm{fad}^{-1}$ & & 14.63 & 14.19 & 0.91 & 0.78 \\
\hline $72 \mathrm{~kg} \mathrm{~N} \mathrm{fad}^{-1}+\mathrm{C}$ & & 25.10 & 24.60 & 1.17 & 0.97 \\
\hline $54 \mathrm{~kg} \mathrm{~N} \mathrm{fad}^{-1}+\mathrm{C}$ & & 22.61 & 22.26 & 1.12 & 0.87 \\
\hline $36 \mathrm{~kg} \mathrm{~N} \mathrm{fad}^{-1}+\mathrm{C}$ & & 14.91 & 14.20 & 0.92 & 0.78 \\
\hline $72 \mathrm{~kg} \mathrm{~N} \mathrm{fad}^{-1}+\mathrm{R}$ & & 25.61 & 25.10 & 1.21 & 0.98 \\
\hline $54 \mathrm{~kg} \mathrm{~N} \mathrm{fad}^{-1}+\mathrm{R}$ & & 22.75 & 22.35 & 1.12 & 0.90 \\
\hline $36 \mathrm{~kg} \mathrm{~N} \mathrm{fad}^{-1}+\mathrm{R}$ & & 14.93 & 14.28 & 0.92 & 0.79 \\
\hline L.S.D & & 0.513 & 2.572 & 0.466 & 0.495 \\
\hline
\end{tabular}

$\mathrm{N}=$ nitrogen, $\mathrm{C}=$ Cerealine, $\mathrm{R}=$ Rizobacterin, $\mathrm{LSD}=$ least significant difference. 
The data in both seasons showed that increasing faba bean sowing distance from 10 to $30 \mathrm{~cm}$ resulted in a significant increase at root diameter $(\mathrm{cm})$, fresh leaves weight/plant, fresh root weight/plant, dry leaves weight /plant, dry root weight /plant and root yield/fad $\left(\right.$ ton $\left.\mathrm{fad}^{-1}\right)$ while number of leaves /plant showed increasing in the first seasons only where the $30 \mathrm{~cm}$ sowing distance gave the greatest values at all previous mentioned traits while the sowing distance of 10 $\mathrm{cm}$ recorded the lowest values in all previous mentioned characters. The same treatments showed that decreasing at root length $(\mathrm{cm})$, sugars percent $(\%)$, purity percent and TSS (\%) of sugar beet in 2013/2014 and 2014/2015 seasons. The data revealed that sowing distance of $10 \mathrm{~cm}$ recorded the highest values in all previous mentioned traits but the $30 \mathrm{~cm}$ sowing distance gave the lowest values at the same mentioned characters. Such favorable effect of bean sowing distance on growth characters might have been resulted from the increase the volume of plant roots, which increased vegetative growth, photosynthetic area, which resulted in more assimilates products and consequently increased dry matter accumulation and translocation of more photosynthesis to seeds. These results are in agreement with those obtained by Mohammed et al. (2005), Abo-Elela (2012), Abdel Motagally et al. (2014) and El-Shamy et al. (2015).

The interaction between the faba bean sowing distance and the combination between mineral nitrogen levels and bio fertilizers (Cerealine and Rizobacterin), had a significant effect on number of leaves /plant, Fresh leaves weight (gm) / plant, fresh root weight (gm) /plant, and dry root weight/plant in first season and TSS \% of sugar beet in the second season, There are significant differences in the root yield tonfad ${ }^{-1}$ in both seasons.

Data in Table 8 showed that the effect of interaction between faba bean sowing distance and combinations between mineral nitrogen levels and bio fertilizers (Cerealine and Rizobacterin) on root yield fad ${ }^{-1}$ and seed yield fad ${ }^{-1}$ of faba bean in both seasons. The interactions between $10 \mathrm{~cm}$ sowing distance of faba bean and $36 \mathrm{~kg}$ showed the lowest values of sugar beet root yield tonfad ${ }^{-1}$ and faba bean seeds yield tonfad ${ }^{-1}$ without a significantly differences compared with other interactions, the interaction between $30 \mathrm{~cm}$ sowing distance of faba bean with $90 \mathrm{~kg}$ mineral nitrogen as individual or $72 \mathrm{~kg}$ mineral nitrogen as individual or in combination with Cerealine or Rizobacterien gave the highest significant values of sugar beet root yield tonfad ${ }^{-1}$ and faba bean seeds yield tonfad $^{-1}$ without a significantly differences compared with the other interactions, followed by the interaction between $20 \mathrm{~cm}$ sowing distance of faba bean with 90 $\mathrm{kg}$ mineral nitrogen as individual or $72 \mathrm{~kg}$ mineral nitrogen as individual or in combination with Cerealine or Rizobacterien in both traits. These results may be due to the effect of nitrogen levels and biofertilizer on soil activity and characters, added to that the effect of sowing distance on optimum plant distribution in the field, all that improve nutrient mobilization from organic and chemical fertilizers which is closely related to the amount of absorbed nitrogen and then improve translocation of assimilates and thus improve the growth and yield characters. Similar results were obtained by Abdel Motagally et al. (2014).

Egypt. J. Agron. Vol. 38, No.3(2016) 
The data in Tables 9 and 10 revealed that the highest values of relative yield (RY), LER and net income of faba bean and sugars beet were obtained from the interaction between $30 \mathrm{~cm}$ sowing distance of faba bean with $90 \mathrm{~kg}$ mineral nitrogen as individual or $\mathbf{7 2} \mathrm{kg}$ mineral nitrogen as individual or in combination with Cerealine or Rizobacterien in both growing seasons followed by the combinations between $30 \mathrm{~cm}$ faba bean sowing distance and $54 \mathrm{~kg}$ mineral nitrogen as individual or in combination with Cerealine or Rizobacterien but the lowest values of those characters were recorded at the interaction between $10 \mathrm{~cm}$ faba bean sowing distance $36 \mathrm{~kg}$ mineral nitrogen as individual or in combination with Cerealine or Rizobacterien in both growing seasons. Such favorable effect of faba bean sowing distance on those characters might have been resulted from improve in faba bean and sugar beet productivity which reverse on relative yield (RY), net income for faba bean and sugar beet and land equivalent ratio (LER). These results are in accordance with those obtained by Mohammed et al. (2005), Abo-Elela (2012), Abdel Motagally et al. (2014) and El-Shamy et al. (2015).

TABLE 9. Relative yield (RY), LER and net income of faba bean and sugar beet (Beta vulgaris) and as affected by faba bean sowing distance and combinations between mineral nitrogen levels and bio fertilizers sources (Cerealine or Rizobacterien) and their interaction during 2013/2014 seasons.

\begin{tabular}{|c|c|c|c|c|c|c|c|}
\hline \multirow{2}{*}{\multicolumn{2}{|c|}{$\begin{array}{l}\text { Combinations of mineral } \mathrm{N} \\
\text { and bio fertilizers }\end{array}$}} & \multicolumn{2}{|c|}{$\begin{array}{c}\text { Relative yield } \\
\text { (RY) }\end{array}$} & \multirow[t]{2}{*}{ LER } & \multicolumn{2}{|c|}{ Net income for } & \multirow[t]{2}{*}{$\begin{array}{c}\text { Total net } \\
\text { income }\end{array}$} \\
\hline & & $\begin{array}{l}\text { Faba } \\
\text { bean }\end{array}$ & $\begin{array}{c}\text { Sugar } \\
\text { beet }\end{array}$ & & $\begin{array}{l}\text { Faba } \\
\text { bean }\end{array}$ & $\begin{array}{c}\text { Sugar } \\
\text { beet }\end{array}$ & \\
\hline $90 \mathrm{~kg} \mathrm{~N} \mathrm{fad}^{-1}$ (Control) & \multirow{10}{*}{$10 \mathrm{~cm}$} & 0.112 & 0.649 & 0.760 & 6666.00 & 5917.50 & 12583.5 \\
\hline $72 \mathrm{~kg} \mathrm{~N} \mathrm{fad}^{-1}$ & & 0.110 & 0.635 & 0.745 & 6532.68 & 5793.75 & 12326.43 \\
\hline $54 \mathrm{~kg} \mathrm{~N} \mathrm{fad}^{-1}$ & & 0.104 & 0.618 & 0.722 & 6199.38 & 5640.00 & 11839.38 \\
\hline $36 \mathrm{~kg} \mathrm{~N} \mathrm{fad}^{-1}$ & & 0.091 & 0.485 & 0.571 & 5399.46 & 4383.75 & 9783.2 \\
\hline $72 \mathrm{~kg} \mathrm{~N} \mathrm{fad}^{-1}+\mathrm{C}$ & & 0.111 & 0.640 & 0.751 & 6599.34 & 5842.50 & 12441.84 \\
\hline $54 \mathrm{~kg} \mathrm{~N} \mathrm{fad}^{-1}+\mathrm{C}$ & & 0.107 & 0.632 & 0.740 & 6399.36 & 5767.50 & 12166.86 \\
\hline $36 \mathrm{~kg} \mathrm{~N} \mathrm{fad}^{-1}+\mathrm{C}$ & & 0.092 & 0.493 & 0.585 & 5466.12 & 4500.00 & 9966.1 \\
\hline $72 \mathrm{~kg} \mathrm{~N} \mathrm{fad}^{-1}+\mathrm{R}$ & & 0.111 & 0.647 & 0.758 & 6599.34 & 5902.50 & 12501.84 \\
\hline $54 \mathrm{~kg} \mathrm{~N} \mathrm{fad}^{-1}+\mathrm{R}$ & & 0.109 & 0.634 & 0.743 & 6466.02 & 5786.25 & 12252.27 \\
\hline $36 \mathrm{~kg} \mathrm{~N} \mathrm{fad}^{-1}+\mathrm{R}$ & & 0.094 & 0.508 & 0.603 & 5599.44 & 4638.75 & 10238.19 \\
\hline $90 \mathrm{~kg} \mathrm{~N} \mathrm{fad}^{-1}$ (Control) & \multirow{10}{*}{$20 \mathrm{~cm}$} & 0.130 & 1.001 & 1.131 & 7732.56 & 9135.00 & 16867.56 \\
\hline $72 \mathrm{~kg} \mathrm{~N} \mathrm{fad}^{-1}$ & & 0.113 & 0.863 & 0.976 & 6732.66 & 5.00 & 7.66 \\
\hline $54 \mathrm{~kg} \mathrm{~N} \mathrm{fad}^{-1}$ & & 0.112 & 0.652 & 0.763 & 6666.00 & 5943.75 & 12609.75 \\
\hline $36 \mathrm{~kg} \mathrm{~N} \mathrm{fad}^{-1}$ & & 0.094 & 0.529 & 0.623 & 5599.44 & 4830.00 & 10429.44 \\
\hline $72 \mathrm{~kg} \mathrm{~N} \mathrm{fad}^{-1}+\mathrm{C}$ & & 0.128 & 0.961 & 1.089 & 7599.24 & 8771.25 & 16370.49 \\
\hline $54 \mathrm{~kg} \mathrm{~N} \mathrm{fad}^{-1}+\mathrm{C}$ & & 0.115 & 0.899 & 1.013 & 6799.32 & 8201.25 & 15000.57 \\
\hline $36 \mathrm{~kg} \mathrm{~N} \mathrm{fad}^{-1}+\mathrm{C}$ & & 0.101 & 0.585 & 0.689 & 5999.40 & 5340.00 & 11339.4 \\
\hline $72 \mathrm{~kg} \mathrm{~N} \mathrm{fad}^{-1}+\mathrm{R}$ & & 0.129 & 0.971 & 1.010 & 7665.90 & 8861.25 & 16527.15 \\
\hline $54 \mathrm{~kg} \mathrm{~N} \mathrm{fad}^{-1}+\mathrm{R}$ & & 0.122 & 0.916 & 1.038 & 7265.94 & 8358.75 & 15624.69 \\
\hline $36 \mathrm{~kg} \mathrm{~N} \mathrm{fad}^{-1}+\mathrm{R}$ & & 0.102 & 0.599 & 0.702 & 6066.06 & 5471.25 & 11537.31 \\
\hline $90 \mathrm{~kg} \mathrm{~N} \mathrm{fad}^{-1}$ (Contr & \multirow{10}{*}{$30 \mathrm{~cm}$} & 0.134 & 1.042 & 1.176 & 7999.20 & 9506.25 & 17505.45 \\
\hline $72 \mathrm{~kg} \mathrm{~N} \mathrm{fad}^{-1}$ & & 0.128 & 0.954 & 1.082 & 7599.24 & 8703.75 & 16302.99 \\
\hline $54 \mathrm{~kg} \mathrm{~N} \mathrm{fad}^{-1}$ & & 0.113 & 0.668 & 0.781 & 6732.66 & 6093.75 & 12826.41 \\
\hline $36 \mathrm{~kg} \mathrm{~N} \mathrm{fad}^{-1}$ & & 0.102 & 0.601 & 0.703 & 6066.06 & 5486.25 & 11552.31 \\
\hline $72 \mathrm{~kg} \mathrm{~N} \mathrm{fad}^{-1}+\mathrm{C}$ & & 0.133 & 1.032 & 1.163 & 7799.22 & 9412.50 & 17211.72 \\
\hline $54 \mathrm{~kg} \mathrm{~N} \mathrm{fad}^{-1}+\mathrm{C}$ & & 0.125 & 0.929 & 1.055 & 7465.92 & 8478.75 & 15944.67 \\
\hline $36 \mathrm{~kg} \mathrm{~N} \mathrm{fad}^{-1}+\mathrm{C}$ & & 0.103 & 0.613 & 0.716 & 6132.72 & 5591.25 & 11723.97 \\
\hline $72 \mathrm{~kg} \mathrm{~N} \mathrm{fad}^{-1}+\mathrm{R}$ & & 0.135 & 1.053 & 1.188 & 8065.86 & 9603.75 & 17669.61 \\
\hline $54 \mathrm{~kg} \mathrm{~N} \mathrm{fad}^{-1}+\mathrm{R}$ & & 0.125 & 0.935 & 1.060 & 7465.92 & 8531.25 & 15997.17 \\
\hline $36 \mathrm{~kg} \mathrm{~N} \mathrm{fad}^{-1}+\mathrm{R}$ & & 0.103 & 0.614 & 0.717 & 6132.72 & 5598.75 & 11731.47 \\
\hline
\end{tabular}

\begin{tabular}{|l|l|l|l|l|l|l|}
\hline $36 \mathrm{~kg} \mathrm{~N} \mathrm{fad}^{-1}+\mathrm{R}$ & 0.103 & 0.614 & 0.717 & 6132.72 & 5598.75 & 11731.47 \\
\hline
\end{tabular}

$\mathrm{N}=$ nitrogen, $\mathrm{C}=$ Cerealine and $\mathrm{R}=$ Rizobacterin, total income for solid crops sugar beet: LE 2685.75, Faba bean: LE 4408, Solid sugar beet root yield: 24.33 ton $\mathrm{fad}^{-1}$ 
TABLE 10. Relative yield (RY), LER and net income of faba bean and sugar beet (Beta vulgaris) and as affected by faba bean sowing distance and combinations between mineral nitrogen levels and bio fertilizers sources (Cerealine or Rizobacterien) and their interaction during 2014/2015 seasons.

\begin{tabular}{|c|c|c|c|c|c|c|c|}
\hline \multirow{2}{*}{\multicolumn{2}{|c|}{$\begin{array}{c}\begin{array}{c}\text { Combinations of mineral } N \\
\text { and bio fertilizers }\end{array} \\
\end{array}$}} & \multicolumn{2}{|c|}{$\begin{array}{c}\text { Relative yield } \\
\text { (RY) }\end{array}$} & \multirow{3}{*}{$\begin{array}{l}\text { LER } \\
\\
0.743 \\
\end{array}$} & \multicolumn{2}{|c|}{ Net income for } & \multirow{3}{*}{$\begin{array}{l}\begin{array}{c}\text { Total net } \\
\text { income }\end{array} \\
11363.2\end{array}$} \\
\hline & & Faba & Sugar & & faba & sugar & \\
\hline $90 \mathrm{~kg} \mathrm{~N} \mathrm{fad}^{-1}$ (Control) & \multirow{10}{*}{$10 \mathrm{~cm}$} & 0.093 & 0.650 & & 5599.44 & 5763.75 & \\
\hline $72 \mathrm{~kg} \mathrm{~N}$ fad $^{-1}$ & & 0.091 & 0.632 & 0.723 & 5466.12 & 5602.50 & 11068.6 \\
\hline $54 \mathrm{~kg} \mathrm{~N}$ fad $^{-1}$ & & 0.088 & 0.613 & 0.701 & 5266.14 & 5437.50 & 10703.6 \\
\hline $36 \mathrm{~kg} \mathrm{~N} \mathrm{fad}^{-1}$ & & 0.069 & 0.424 & 0.492 & 4132.92 & 3757.50 & 7890.4 \\
\hline $72 \mathrm{~kg} \mathrm{~N} \mathrm{fad}^{-1}+\mathrm{C}$ & & 0.091 & 0.638 & 0.729 & 5466.12 & 5658.75 & 11124.9 \\
\hline $54 \mathrm{~kg} \mathrm{~N} \mathrm{fad}^{-1}+\mathrm{C}$ & & 0.089 & 0.618 & 0.707 & 5332.80 & 5482.50 & 10815.3 \\
\hline $36 \mathrm{~kg} \mathrm{~N} \mathrm{fad}^{-1}+\mathrm{C}$ & & 0.071 & 0.482 & 0.553 & 4266.24 & 4275.00 & 8541.2 \\
\hline $72 \mathrm{~kg} \mathrm{~N} \mathrm{fad}^{-1}+\mathrm{R}$ & & 0.093 & 0.647 & 0.740 & 5599.44 & 5733.75 & 11333.2 \\
\hline $54 \mathrm{~kg} \mathrm{~N} \mathrm{fad}^{-1}+\mathrm{R}$ & & 0.090 & 0.619 & 0.709 & 5399.46 & 5490.00 & 10889.5 \\
\hline $36 \mathrm{~kg} \mathrm{~N} \mathrm{fad}^{-1}+\mathrm{R}$ & & 0.071 & 0.495 & 0.566 & 4266.24 & 4387.50 & 8653.7 \\
\hline $90 \mathrm{~kg} \mathrm{~N} \mathrm{fad}^{-1}$ (Control) & \multirow{10}{*}{$20 \mathrm{~cm}$} & 0.108 & 1.007 & 1.114 & 6466.02 & 8928.75 & 15394.9 \\
\hline $72 \mathrm{~kg} \mathrm{~N}$ fad $^{-1}$ & & 0.094 & 0.895 & 0.989 & 5666.10 & 7935.00 & 13601.1 \\
\hline $54 \mathrm{~kg} \mathrm{~N} \mathrm{fad}^{-1}$ & & 0.093 & 0.657 & 0.750 & 5599.44 & 5823.75 & 11423.2 \\
\hline $36 \mathrm{~kg} \mathrm{~N} \mathrm{fad}^{-1}$ & & 0.072 & 0.510 & 0.582 & 4332.90 & 4522.50 & 8855.4 \\
\hline $72 \mathrm{~kg} \mathrm{~N} \mathrm{fad}^{-1}+\mathrm{C}$ & & 0.106 & 0.969 & 1.075 & 6399.36 & 8591.25 & 14990.6 \\
\hline $54 \mathrm{~kg} \mathrm{~N} \mathrm{fad}^{-1}+\mathrm{C}$ & & 0.095 & 0.913 & 1.008 & 5732.76 & 8096.25 & 13829.0 \\
\hline $36 \mathrm{~kg} \mathrm{~N} \mathrm{fad}^{-1}+\mathrm{C}$ & & 0.080 & 0.526 & 0.606 & 4799.52 & 4665,00 & 9464.5 \\
\hline $72 \mathrm{~kg} \mathrm{~N} \mathrm{fad}^{-1}+\mathrm{R}$ & & 0.106 & 0.978 & 1.085 & 6399.36 & 8677.50 & 15076.9 \\
\hline $54 \mathrm{~kg} \mathrm{~N} \mathrm{fad}^{-1}+\mathrm{R}$ & & 0.095 & 0.926 & 1.021 & 5732.76 & 8212.50 & 13945.3 \\
\hline $36 \mathrm{~kg} \mathrm{~N} \mathrm{fad}^{-1}+\mathrm{R}$ & & 0.084 & 0.589 & 0.671 & 5066.16 & 5205.00 & 10271.2 \\
\hline $90 \mathrm{~kg} \mathrm{~N}$ fad $^{-1}$ (Control) & \multirow{10}{*}{$30 \mathrm{~cm}$} & 0.109 & 1.051 & 1.159 & 6532.68 & 9318.75 & 15851.4 \\
\hline $72 \mathrm{~kg} \mathrm{~N}$ fad $^{-1}$ & & 0.101 & 0.964 & 1.065 & 6066.06 & 8550.00 & 14616.1 \\
\hline $54 \mathrm{~kg} \mathrm{~N} \mathrm{fad}^{-1}$ & & 0.094 & 0.672 & 0.767 & 5666.10 & 5962.50 & 11628.6 \\
\hline $36 \mathrm{~kg} \mathrm{~N} \mathrm{fad}^{-1}$ & & 0.087 & 0.600 & 0.687 & 5199.48 & 5321.25 & 10520.7 \\
\hline $72 \mathrm{~kg} \mathrm{~N} \mathrm{fad}^{-1}+\mathrm{C}$ & & 0.108 & 1.040 & 1.148 & 6466.02 & 9225.00 & 15691.0 \\
\hline $54 \mathrm{~kg} \mathrm{~N} \mathrm{fad}^{-1}+\mathrm{C}$ & & 0.097 & 0.941 & 1.038 & 5799.42 & 8347.50 & 14146.9 \\
\hline $36 \mathrm{~kg} \mathrm{~N} \mathrm{fad}^{-1}+\mathrm{C}$ & & 0.087 & 0.600 & 0.687 & 5199.48 & 5325.00 & 10524.5 \\
\hline $72 \mathrm{~kg} \mathrm{~N} \mathrm{fad}^{-1}+\mathrm{R}$ & & 0.109 & 1.061 & 1.170 & 6532.68 & 9412.50 & 15945.2 \\
\hline $54 \mathrm{~kg} \mathrm{~N} \mathrm{fad}^{-1}+\mathrm{R}$ & & 0.10 & 0.945 & 1.045 & 5999.40 & 8381.25 & 14380.7 \\
\hline $36 \mathrm{~kg} \mathrm{~N} \mathrm{fad}^{-1}+\mathrm{R}$ & & 0.088 & 0.604 & 0.692 & 5266.14 & 5355.00 & 10621.1 \\
\hline
\end{tabular}

$\mathrm{N}=$ nitrogen, $\mathrm{C}=$ Cerealine and $\mathrm{R}=$ Rizobacterin, total income for solid crops sugar beet: LE 2685.75, Faba

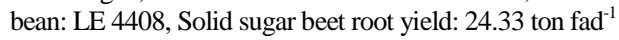

Egypt. J. Agron. Vol. 38, No.3(2016) 


\section{Conclusion}

From the results and under the conditions of this study, It could be concluded that he highest productivity and best total net income of faba bean and sugars beet resulted from planting of faba bean at distance $30 \mathrm{~cm}$ under intercropping system with sugar beet with application of $72 \mathrm{~kg}$ mineral nitrogen in combination with bio fertilizers (Cerealine or Rizobacterien).

\section{References}

Abdel Motagally, F. M. F. and Metwally, A. K. (2014) Maximizing productivity by intercropping onion on sugar beet. Asian Journal of Crop Science, 6, 226-235.

Abou-Elela, A. M. (2012) Effect of intercropping system and sowing dates of wheat intercropping with sugar beet. J. Plant Production, Mansoura Univ. 3 (12), 3101 3116.

AlJubouri, A.H.A. (2006) Effect of plant densities on the yield of beans (Vicia faba L.) varieties, Master Thesis, Faculty of Agriculture, University of Tikrit.

A.O.A.C. (1990) "Official Methods of the Analysis". Association of Official Agricultural Methods. $15^{\text {th }}$ ed, Published by Association of Official Analytical Chemists, Arlington, Virginia, USA.

Black, C.A., Evans, D.D., Ensminger, L.E., White, J.L. and Clark, F.E. (1965) "Methods of Soil Analysis (Chemical and Microbiological Properties", Part 2. American Society of Agronomy, Inc., Publisher Madison, Wisconsin.

El-Shamy, Moshira A., Moursi, E. A. and EL-Mansoury, Mona A. M. (2015) Maximizing water productivity by intercropping onion on surgar beet in the North Middle Nile Delta Region. J. Soil Sci. and Agric . Eng., Mansoura Univ. 6, 961-982.

Gomez, K. A. and Gomez, A. A. (1984) "Statistical Procedures for the Agricultural Researches". John Wiley and Son.Inc. New York.

Hansen, W.R. (1972) Net photo synthetis and evapotrenspiration of fild - grown soybean canopies. Ph.D. Thesis. Iowa State University Library, Ames.

Hussein, M. M. M. and EL-Deeb, Yousrya S. A. M. (2012) Effect of intercropping flax in different seeding rates in fields of sugar beet under nitrogen fertilization levels on yield, quality and land use efficiency attributes. Zagazig J. Agric. Res. 39, 9-29.

Jackson, M.l. (1973) “Soil Chemical Analysis”. Prentice Hall of India private, LTD New Delhi.

Kakahy, A. N. N., Ahmad, D. and Abdullahi, A. S. (2012) The effect of planting distance on yield of beans (Vicia faba L.) under drip irrigation system. African Journal of Agricultural Research, 7(46), 6110-6114. 
Mahmoud, E. A., Ramadan, B.S.H., El -Geddawy, I.H. and Korany, Samah F. (2014) Effect of mineral and biofertilization on productivity of sugar beet. J. Plant Production, Mansoura Uni. 5 (4), 699 - 710.

Mohammed, Wafaa KH. , El-Metwally, E. A. and Saleh, S.A. (2005) Intercropping faba bean at different plant densities with sugar beet, Egypt. J. Agric. Res. 83(2), 649-663.

Waller, R. A., and Duncan, D. B. (1969) A Bayes rule for the symmetric multiple comparison problem, Journal of the AmericanStatisticalAssociation, 64, 1484-1503.

Willey R.W. and Osiru, D. S. (1972) Studies of mixtures of maize and beans (Phaseolus vulgaris) with particular reference to plant population. J. Agric. Sci. 79, 517-529.

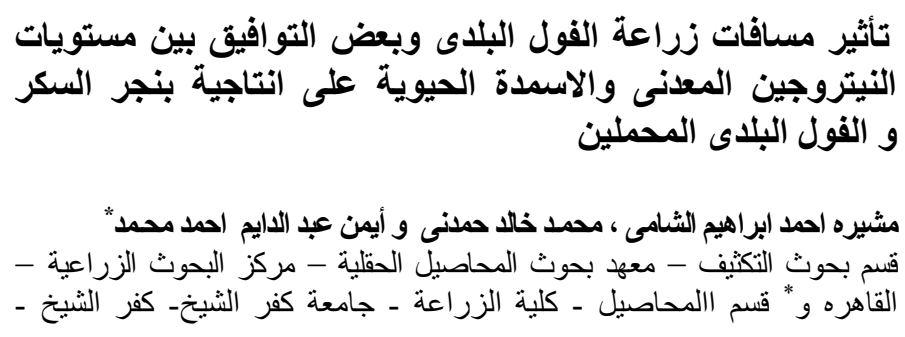

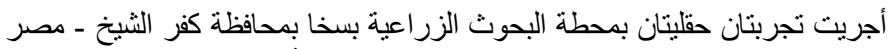

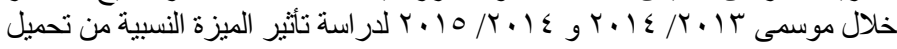

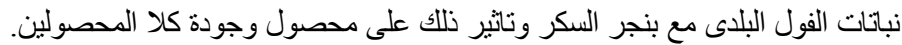

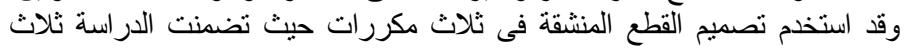

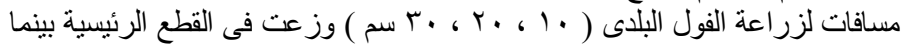

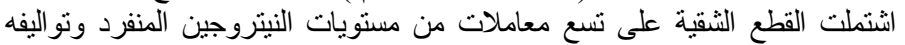

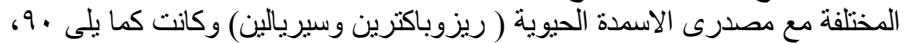

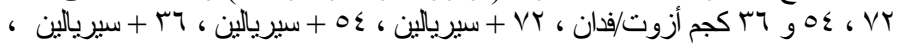

Tr

المتحصل عليها ما يلى :-

Egypt. J. Agron. Vol. 38, No.3(2016) 


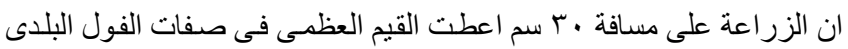

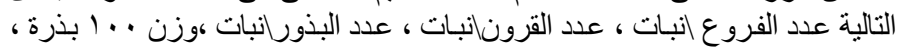

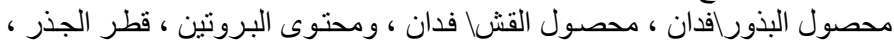

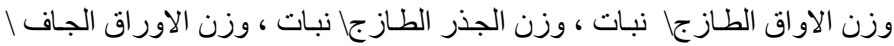

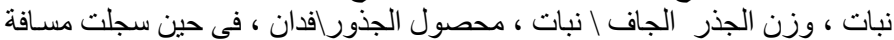

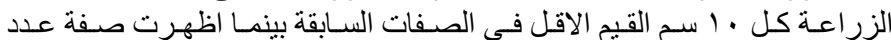

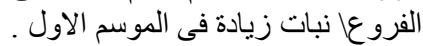

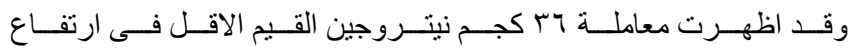

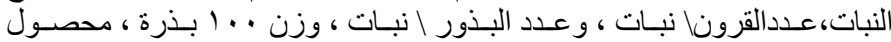

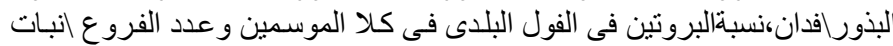

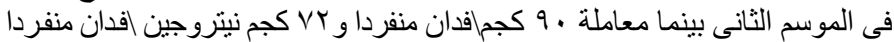

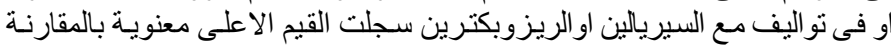

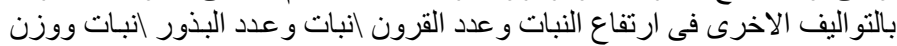

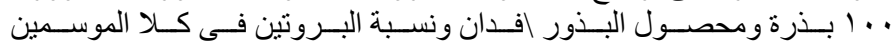
و عددالفروعانبات فى الموسم الثانى.

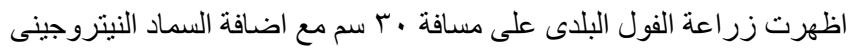

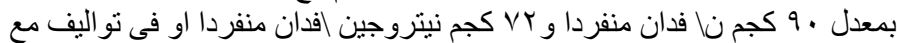

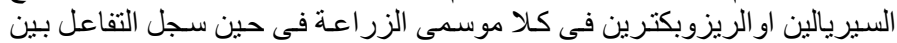

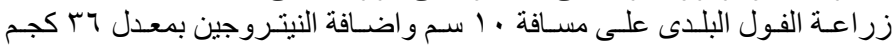

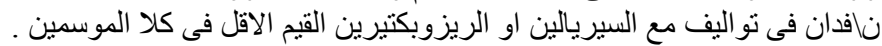

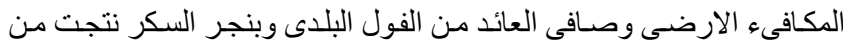

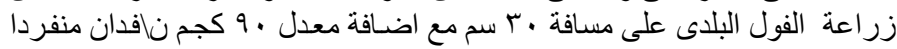

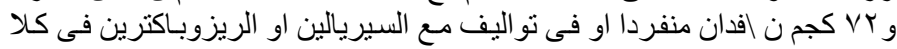

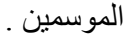

من النتائج السابقة يمكن التوصية بان زراعة الفول البلدى محملا على بنجر

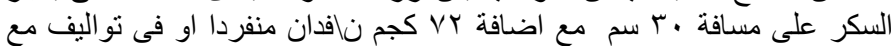

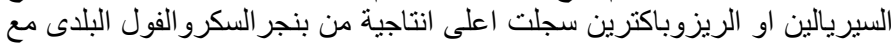

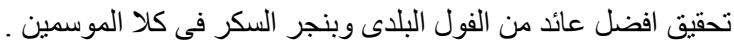

